\title{
Ramularia leaf spot: PCR-based methods reveal widespread distribution of Ramulariopsis pseudogycines and limited presence of $R$. gossypii in Brazil
}

\author{
Aline Suelen Silva \\ Universidade de Brasília \\ Marcelo Henrique Lisboa Renno \\ Universidade de Brasília \\ Ana Clara Ribeiro Quitania \\ Universidade de Brasília \\ Adalberto Correa CaféFilho \\ Universidade de Brasília \\ Robert Neil Gerard Miller \\ Universidade de Brasília \\ Alderi Emidio Araujo \\ Empresa Brasileira de Pesquisa Agropecuária \\ Danilo Batista Pinho ( $\nabla$ danilopinho@unb.br) \\ Universidade de Brasília
}

\section{Research Article}

Keywords: Diagnosis, Etiology, Morphology, Mycosphaerella, Taxonomy

Posted Date: April 29th, 2021

DOI: https://doi.org/10.21203/rs.3.rs-477759/v1

License: (c) (i) This work is licensed under a Creative Commons Attribution 4.0 International License.

Read Full License 


\section{Abstract}

Whilst Brazil is the fourth largest cotton producer globally, incidence of ramularia leaf spot (RLS) has decreased yield across all growing regions. In 2017-18 and 2018-19 growing seasons, ca. 300 fungal samples were collected from seven Brazilian states. Hyphal tip cultures were obtained for DNA extraction and amplification of partial sequences of the RNA polymerase II gene (RPB2), 28S rRNA, the ribosomal DNA internal transcribed spacers (ITS), actin (ACT), elongation factor (EF1- $a$ ) and histone H3 (HIS3) gene regions. Genetic diversity of the isolates was evaluated using fourteen molecular markers. Clade assignments based on the concatenated-sequence tree (RPB2, LSU, EF1- $a$, ITS, ACT, and HIS3) were identical to those in tree clades generated by RPB2-sequences, as well as in an RPB2 haplotype network, in an ISSR (TGTC) ${ }^{4}$ dendrogram, and based on morphological comparisons. In total, 252 out of 267 isolates were identified as Ramulariopsis pseudoglycines, indicating this species as the most widespread causal agent of cotton RLS in the Brazilian growing regions today. Validation of the ISSR (TGTC) ${ }^{4}$ primer as a tool to study the diversity and distribution of Ramulariopsis species will make it possible to carry out extensive RLS sampling studies worldwide.

\section{Introduction}

Cotton (Gossypium spp.) is the world's most cultivated fiber crop, mostly for the supply of raw materials for the textile industry, as well as for oil and protein extraction ${ }^{1}$. Since the 1990s, Brazil has ranked globally in fourth place in terms of cotton production, following a strong investment in the production technology and in the expansion of cultivated area, mainly in the Brazilian Cerrado $2,3,4,5$ (a savannah-like region in the Brazilian Midwest).

Favorable environmental conditions during the growing season, combined with the cultivation of a limited number of cotton genotypes over very large areas, favors epidemics of ramularia leaf $\operatorname{spot}^{4,6}$. This disease was first reported in Paraguari, Paraguay in $1883^{7}$, then soon after followed by a report from Alabama, USA in $1890^{8}$. Since then, the disease has been reported in more than 40 cotton producing countries $^{9,10}$. Typically, ramularia leaf spot (RLS) is observed at the end of the cotton cycle and is therefore generally considered as a disease of secondary importance.

In Brazil, the disease was first reported by the Agricultural Inspection and Defense Service of São Paulo in 1919 and was considered of secondary importance until the $90^{\prime}{ }^{9,11}$. Currently, RLS is the major cotton disease in Brazil, with up to eight spray applications of fungicide required to reduce its negative effects on yield and cotton fiber quality $4,5,12$.

Historically, Ramularia areola was the specific epithet used to designate the causal agent of RLS ${ }^{13}$. In 1961, this species was recombined to Ramularia gossypii (Speg.) Cif. and, due to the morphological similarities with the related genus Ramulariopsis (conidiophores severely branched at the base with terminal and lateral conidiogenic cells), the pathogen recombined again in 1993 to Ramulariopsis 
gossypii (Speg.) Braun ${ }^{14}$. Later, a multigenic study including a representative number of isolates of Ramularia and allied genera revealed a new species, Ramulariopsis pseudoglycines, associated with $\mathrm{RLS}^{15}$.

In Brazil, the etiology of the disease is so far inaccurate, given that most identifications are based on only few isolates or limited to the examination of morphological data ${ }^{15,16,17}$. Furthermore, it has been shown that a molecular perspective, associated with morphological data, is required to resolve plant pathogen species complexes, with this combined approach effective in revealing previously uncharacterized species affecting different crops ${ }^{15,18,19}$. For example, molecular characterization of isolates previously identified as Ramularia eucalypti based exclusively on morphological comparisons revealed a total of seven species associated with the eucalyptus leaf $\operatorname{spot}^{20}$.

The diverse reactions of resistant and susceptible genotypes of cotton to different isolates of Ramulariopsis has been ascribed to the genetic variability of the pathogen ${ }^{21}$. Recently, an analysis of the genetic diversity of 16 isolates of Ramulariopsis revealed three genetic groups ${ }^{22}$. This information indicates a greater variability of the causal agent of the RLS than has so far been acknowledged. Nevertheless, there are still relatively few studies addressing the genetic diversity of Ramulariopsis associated to cotton in Brazil ${ }^{4,21,22,23}$.

Accurate identification of the RLS pathogen in Brazil, as well as the relative abundancy of each causal agent, and respective geographic distribution, are particularly important for disease management recommendations, and are paramount for cotton breeding programs. The precise identification of the Ramulariopsis species in each growing area, combined with the phytosanitary measures, can minimize damage caused by RLS.

Here, Ramulariopsis isolates collected in the main cotton growing regions in Brazil were morphologically and molecularly characterized. In addition, a PCR-based method was developed to distinguish between isolates of R. gossypii and R. pseudoglycines, aiding breeders and plant pathologists in cotton disease resistance development and fungicide resistance avoidance.

\section{Results}

\section{Sampling and Isolates}

Symptomatic leaf samples were collected from 24 production fields representing seven Brazilian states (Fig. 1). Naturally-occurring symptoms included light green to yellow-green lesions delimited by the veinlets, giving them an angular or irregular shape, with white powdery sporulation on both sides of the leaves. Under favorable disease conditions, the lesions coalesced, become chlorotic and then necrotic, and often followed by severe defoliation (Fig. 2). Two hundred and sixty-seven Ramulariopsis isolates (Supplementary Table S1) were obtained in the Brazilian states of Bahia $(n=44)$, Distrito Federal $(n=32)$, Goiás ( $n=31)$, Maranhão $(n=30)$, Mato Grosso $(n=87)$, Mato Grosso do Sul $(n=39)$ and Paraíba $(n=4)$. 


\section{Phylogenetic analysis}

$R P B 2$ amplicons were obtained for 267 isolates, generating sequences of approximately $930 \mathrm{bp}$, which were deposited in GenBank under accession nos. MZ039858 to MZ040124. The RPB2 matrix included 271 taxa (267 isolates from this study and 4 taxa from GenBank), composed of 847 sites (740 conserved) and 91 parsimony-informative characters. The BI tree was reconstructed using the GTR nucleotide substitution model. The RPB2 tree (Fig. 3) showed that the Ramulariopsis isolates were grouped into two distinct clades (the nucleotide matrices and phylogenetic tree are available in TreeBASE; study number S28159). Clade II gathered most (94.4\%) of the isolates from the states of Bahia (44), Distrito Federal (21), Goiás (31), Maranhão (30), Mato Grosso (87) and Mato Grosso do Sul (39). The remaining 15 isolates (5.6\%) were grouped in Clade I, with 11 isolates from the Distrito Federal and four from the state of Paraíba.

To correctly delimit the Ramulariopsis isolates at the species level, a multilocus approach was adopted using the RPB2, LSU, EF1-a, ITS, ACT, and HIS3 sequences. A total of 21 taxa (Supplementary Table S2) were included in the BI and ML phylogenetic analyses. The RPB2, LSU, EF1-a, ITS, ACT, and HIS3 individually aligned data sets were $942,873,1112,182,156$, and 346 bp in length, respectively (single gene trees are available in TreeBASE; study number S28159). The concatenate alignment comprised 3611 characters, with 3316 and 281 conserved and variable sites, respectively. Also, 279 sites were determined as phylogenetically informative. The Bayesian phylogenetic tree was reconstructed considering the best nucleotide substitution model for each partition in the concatenate data, GTR (RPB2), HKY (EF1-a, HIS3, ITS, LSU) and K80 (ACT). The Ramulariopsis isolates reported here were grouped into two distinct phylogenetic clades (Fig. 4), corresponding to $R$. gossypii (clade I) and $R$. pseudoglycines (clade II).

\section{Morphological characterization}

The morphological characteristics of the isolates belonging to R. gossypii and R. pseudoglycines in the concatenated tree matched well with the description of each species (Table 2). The long conidiophores of $R$. pseudoglycines are readily distinguished from the short conidiophores of $R$. gossypii by visualization under stereomicroscope or light microscopy. These morphological differences were recorded by SEM and are illustrated here for the first time (Fig. 5).

\section{Genetic characterization}

A high interspecific polymorphism and low intraspecific polymorphism was observed among Ramulariopsis isolates for all 14 markers. The dendrograms based on the binary matrix produced from the band patterns generated with all markers separately were used to analyze the interspecific diversity of Ramulariopsis (data not shown). The ISSR (TGTC) ${ }^{4}$ molecular marker was selected to estimate the interspecific diversity due to its' simplicity for species discrimination. Only one amplicon of approximately $600 \mathrm{bp}$ was observed for $R$. pseudoglycines, while two amplicons of approximately 1000 and 2000 bp were observed for R. gossypii (Fig. 6). To confirm the efficacy of this molecular marker in 
distinguishing these two Ramulariopsis species from other contaminants or fungal pathogens, amplifications were also performed with Fusarium sp., Colletotrichum sp., Talaromyces sp. and Baudoinia sp., demonstrating the efficiency of the molecular marker to distinguish the two species of Ramulariopsis. The dendrogram of 267 isolates of Ramulariopsis generated by amplification of the (TGTC) ${ }^{4}$ primer (Fig. 7) revealed two distinct clades corresponding to the clades previously observed in the phylogenetic analysis.

\section{Intraspecific diversity}

Analysis of intraspecific genetic variability revealed four distinct haplotypes among the 267 Ramulariopsis sequences (Supplementary table S1). The RPB2 haplotype network (Fig. 8) revealed two distinct clades corresponding to the clades already observed in the phylogenetic tree and the dendrogram. The first clade is restricted only to R. gossypii isolates from the Distrito Federal and Paraíba. The second clade is represented by isolates of $R$. pseudoglycines from multiple geographic regions, including all sampled locations. Two out of three $R P B 2$ haplotypes were represented by only one isolate of $R$. pseudoglycines. All isolates of $R$. gossypii $(\mathrm{n}=15)$ grouped into a single haplotype $(\mathrm{H} 3)$ while 250 out of the 252 isolates belong to the most frequent $R$. pseudoglycines haplotype $(\mathrm{H} 1)$, indicating strong prevalence of clonal populations.

\section{Discussion}

Large-scale studies that investigate RLS etiology and the genetic variation of the causal agent are scarce in the literature. The center of origin of cotton has not been determined, but the main centers of diversity are distributed among Central America, Africa, Arabia and Australia ${ }^{24}$. In most of the countries within these regions, RLS is considered as a disease of secondary importance, in contrast to Brazil.

Global cotton yield has been affected by R. gossypii since $1883^{7}$. Historically, this species is most widespread and economically important in Brazil, although it has been mostly identified using only morphological data ${ }^{4,15}$. Although conidiophore length is useful for separating Ramulariopsis species, taxonomic expertise is required. Interestingly, several isolates previously putatively identified as $R$. gossypii were molecularly identified as $R$. gossypii and $R$. pseudoglycines ${ }^{15}$. Comparison of ITS sequences of the Ramulariopsis isolates deposited in the GenBank (the nucleotide matrices and phylogenetic tree are available in TreeBASE; study number S28159) revealed that $R$. gossypii and $R$. pseudoglycines were described in both previous studies ${ }^{17,25}$, but the prevalence of each species was not determined, due to the limited number of isolates.

Here, the molecular identification of the Ramulariopsis isolates causing RLS on cotton using a polyphasic approach confirmed the existence of $R$. gossypii and R. pseudoglycines in Brazil. In total, 252 out of 267 isolates were identified as $R$. pseudoglycines, indicating this species as the most widespread causal agent of cotton RLS in the Brazilian growing producing regions today. Additionally, isolates of R. gossypii were restricted to small and isolated farms located in the Distrito Federal and the state of Paraíba, while 
isolates of $R$. pseudoglycines were obtained from all sampled locations, and all extensive farms in the Brazilian Cerrado.

The clade assignments based on the concatenated-sequence tree (RPB2, LSU, EF1-a, ITS, ACT, and HIS3) were identical to those generated by RPB2-sequences trees, the RPB2 haplotype network, the ISSR $(\mathrm{TGTC})^{4}$ dendrogram, and the morphological comparisons. The most widely employed genomic regions for Ramulariopsis DNA-based identifications have been based upon the ITS sequences, given both their high copy number and easy amplification, and the availability of universal primers. However, for various fungi, the RPB2 molecular marker has been proposed in place of the ITS sequences, due to the lack of resolution in the latter and the potential presence of non-homologous ITS copies in individual fungal genomes $^{26}$.

On a molecular level, RPB2 sequences are recommended for accurate molecular identification of Ramulariopsis isolates, given its universal application, speed, and the presumption that this molecular marker safely approximates taxonomic expertise. However, this technique is laborious, expensive, and requires time and knowledge of phylogenetic analysis for identifying the species ${ }^{27}$. The desire for rapid, automated approaches, such as that obtained here using the ISSR (TGTC) ${ }^{4}$ primer, indicates that the $R P B 2$ region can potentially be used for easy and inexpensive diagnosis and detection assays.

This study showed that the ISSR (TGTC) ${ }^{4}$ primer can be used for accurate molecular identification of Ramulariopsis isolates, facilitating large scale surveys of the distribution of species and monitoring of epidemics. Prior to this study, the diversity among isolates of Ramulariopsis was verified through ERICand REP-PCR profiles for Brazilian isolates ${ }^{22}$ or RAPD profiles for Indian isolates ${ }^{28}$, although in both those studies, only a few isolates were analyzed and accurate identification of the species was not determined.

Considering the wide distribution of haplotype $\mathrm{H} 1$ of $R$. pseudoglycines, there is evidence for a predominant clonal lineage occuring in Brazil, indicating the existence of a highly efficient mechanism of dispersion over long distances. Although RLS caused by R. gossypii has been recognized for a long time, $R$. pseudoglycines seems to be firmly prevalent amongst the cotton-producing regions today. When comparing the morphology of Ramulariopsis specimens from earlier studies ${ }^{4,16}$, the morphological characteristics matched well with the description of $R$. gossypii. We believe that with the cultivation of few cotton genotypes in extensive areas in the Brazilian Cerrado, the population of $R$. pseudoglycines has also increased, becoming one of the most important pathogens negatively impacting cotton production in Brazil.

This is the first large-scale study that investigated the diversity of Ramulariopsis isolates associated to cotton. Validation of the ISSR (TGTC) ${ }^{4}$ primer as a tool to study the diversity and distribution of Ramulariopsis species will make it possible to carry out extensive RLS sampling studies worldwide. Finally, the correct identification of the RLS causal agent and its' geographical distribution is essential for 
predicting resistance breakdown, guiding pesticide regimes and the development of disease resistant genotypes.

\section{Methods}

\section{Sampling and isolation}

Cotton leaves showing typical symptoms of RLS were collected in the 2017-18 and 2018-19 growing seasons from 24 commercial fields in the Brazilian states of Bahia, Distrito Federal, Goiás, Maranhão, Mato Grosso, Mato Grosso do Sul and Paraíba (Fig. 1).

Fungal isolation into pure culture was carried out by the direct method ${ }^{29}$ in Petri dishes containing wateragar (WA) medium ( $20 \mathrm{~g} / \mathrm{L}$ of agar). After 14 days of growth in WA, pure cultures were established by transferring a fragment of a hyphal tip to a new Petri dish containing malt extract (ME) medium ( $20 \mathrm{~g} / \mathrm{L}$ malt extract and $20 \mathrm{~g} / \mathrm{L}$ agar).

Isolates (Supplementary Table S1) were deposited in the Coleção de Culturas da Universidade de Brasília (CCUB; Brasília, Brazil) and stored at $18 \pm 1^{\circ} \mathrm{C}$ in sterile water ${ }^{30}, 10 \%(\mathrm{v} / \mathrm{v})$ sterile glycerol, and half potato-dextrose-agar ( $500 \mathrm{~mL} / \mathrm{L}$ potato broth, $20 \mathrm{~g} / \mathrm{L}$ agar and $20 \mathrm{~g} / \mathrm{L}$ dextrose) slopes covered with sterile mineral oil.

\section{DNA extraction}

Four mycelial discs (5 $\mathrm{mm}$ in diameter) were removed from the margin of 20-day old pure cultures on $\mathrm{ME}$ and transferred to $250 \mathrm{~mL}$ conical flasks containing $50 \mathrm{~mL}$ of potato dextrose broth with addition of streptomycin (500 mL/L potato broth, $20 \mathrm{~g} / \mathrm{L}$ dextrose, $100 \mu \mathrm{g} / \mathrm{mL}$ streptomycin) and incubated at $25^{\circ} \mathrm{C}$, with a $12 \mathrm{~h}$ photoperiod.

After seven days growth, the developed mycelium was recovered on filter paper and transferred to $1.5 \mathrm{~mL}$ microtubes containing $30 \mu \mathrm{L}$ of Tris-EDTA (TE) buffer, four metal beads $(2.8 \mathrm{~mm}$ ), and $600 \mathrm{~mL}$ of Nuclei Lysis Solution (Promega ${ }^{\circledR}$ ). Total DNA extraction was performed using the Wizard Genomic DNA Purification Kit (Promega ${ }^{\circledR}$ ) according to the manufacturer's instructions. Total DNA preparations were analyzed via $1 \%$ agarose gel electrophoresis, stained with GelRed (Biotium R), and visualized under UV light. The DNA samples were stored at $-20 \circ \mathrm{C}$.

\section{Amplification and sequencing}

Partial sequences of the second largest RNA polymerase II subunit (RPB2) were amplified using the specific PCR primers shown in Table 1, with this genomic region employed as the primary barcode for identification of Ramulariopsis species, given the high PCR success rate and easy alignment of the nucleotide sequences. To assign definite species demarcations for the Ramulariopsis isolates, partial nucleotide sequences of five nuclear genes, namely: 28S rRNA ( $L S U)$, the internal transcribed spacers of the ribosomal DNA (ITS), actin (ACT), elongation factor (EF1-a), and histone H3 (HIS3) were obtained 
from representative isolates of different clades and locations preliminarily identified based on $R P B 2$ sequence data (Fig. 3). The primers employed are listed in Table 1, with respective annealing and extension parameters. The PCR mixtures consisted of $6.25 \mu \mathrm{L}$ of MyTaq PCR Master Mix $(2 \times), 0.3 \mu \mathrm{L}$ of each primer (Table 1), $1 \mu \mathrm{L}$ of genomic DNA ( $25 \mathrm{ng} / \mu \mathrm{L})$ and $4.65 \mu \mathrm{L}$ of ultrapure water. The cycling conditions were: Initial denaturation at $95^{\circ} \mathrm{C}$ for $1.5 \mathrm{~min}$, followed at 35 cycles at $95^{\circ} \mathrm{C}$ for $20 \mathrm{~s}$; annealing and extension according to Table 1 and a final extension at $72^{\circ} \mathrm{C}$ for $5 \mathrm{~min}$. The PCR products were purified and bidirectionally Sanger-sequenced.

\section{Phylogenetic analyses}

To determine to which Ramulariopsis species each isolate shared the highest nucleotide identity, the partial nucleotide sequences and the BLASTn algorithm were used to search the NCBI-GenBank nonredundant nucleotide database. A Bayesian phylogenetic tree was initially reconstructed using the $R P B 2$ sequences from the 267 isolates characterized here, and four representative isolates of Ramulariopsis. The ex-epitype CBS 141099 of $R$. gossypii was used as an outgroup. Also, phylogenetic trees were individually inferred from each genomic region analyzed here. Multiple sequence alignments were obtained with MAFFT $v 7^{31}$. Finally, Bayesian Inference (BI) and Maximum Likelihood (ML) phylogenetic trees were reconstructed using the concatenate data (RPB2, LSU, EF1- $a$, ITS, ACT, and HIS3). For $\mathrm{Bl}$, the best nucleotide substitution models were determined, for each partition, with MrModeltest. The CIPRES web portal ${ }^{32}$ was used to run MrBayes v3.2.1 ${ }^{33}$. The Markov Chain Monte Carlo (MCMC) analysis was run with a total of 10 million generations, sampling every 1,000 generations. The convergence of the log likelihoods was confirmed using TRACER v1.7. $1^{34}$. The first $25 \%$ of the sampled trees were discarded as burn-in, with the posterior probability (PP) values calculated with the remaining trees. The ML tree was reconstructed using RAxML v. $8^{35}$, accessed through the CIPRES web portal ${ }^{32}$, assuming a general time reversible (GTR) nucleotide substitution model with a gamma (G) rate of heterogeneity, and 1,000 bootstrap replicates. The phylogenetic trees were visualized and edited in FigTree v1.4 ${ }^{36}$ and Inkscape.

\section{Light microscopy and SEM morphological characterization}

For morphological characterization, specimens were initially observed with a Leica (Leica Biosystems, Nussloch GmbH, Nussloch, Germany) 205C stereomicroscope. The microscopical characteristics were analyzed by mounting asexual structures in clear lactoglycerol, and 50 measurements for each morphological parameter were carried out at a magnification of $\times 1,000$ using a Leica DM2500 light microscope equipped with a Leica DFC 490 digital camera, coupled to a computer containing the Leica Qwin-Plus software. The morphological characteristics of the isolates were compared with the description of $R$. gossypii and R. pseudoglycines ${ }^{14,15}$.

For examination on a scanning electron microscope (JOEL JSM-700 1F model), fragments of symptomatic dry leaves were fixed in $10 \mathrm{~mm}$ diameter copper stubs with double-sided carbon tape and coated with $25 \mathrm{~mA}$ gold, $1.10-2$ mbar, for 2.5 minutes. 


\section{Genetic characterization}

Seventeen isolates of $R$. gossypii $(\mathrm{n}=3)$ and $R$. pseudoglycines $(\mathrm{n}=14)$ were subjected to characterization with different molecular markers (CIIRAP1-4, CIIRAP2-4, REP, ERIC, BOX, M13, N21, CAG5, GA8, GACAC3, TGTC4, GATA4, GTG5 and GACA4) which are typically highly polymorphic and useful in analysis of genetic variability of fungi $22,37,38$.

The PCR amplifications were performed in a final volume of $12.5 \mu \mathrm{L}: 6.25 \mu \mathrm{L}$ of MyTaq PCR Master Mix $(2 \times), 2.5 \mu \mathrm{L}$ of primer, $1 \mu \mathrm{L}$ of genomic DNA $(25 \mathrm{ng} / \mu \mathrm{L})$ and $2.75 \mu \mathrm{L}$ of ultrapure water. Different volumes of primer were used for REP and ERIC $(0.5 \mu \mathrm{l})$, and BOX $(1 \mu \mathrm{l})$ molecular markers, with a final reaction volume again adjusted to $12.5 \mu \mathrm{L}$. The PCR conditions for each molecular marker are shown in references listed in Table 1. Each amplification was repeated at least twice in separated assays.

The amplified products were evaluated as presence (1) or absence (0) of bands and recorded in a binary matrix. This matrix was added to the PAST3 software $^{39}$, where the Jaccard similarity index was calculated for each combination of two samples. From the similarity index, dendrograms were constructed according to the method of unweighted pair group method with arithmetic mean (UPGMA).

\section{Intraspecific diversity}

To characterize intraspecific genetic diversity of $R$. pseudoglycines and $R$. gossypii, an analysis of haplotypes was performed using the RPB2 sequences of the 267 isolates. Haplotype identification was performed using the program DnaSP ver. $5.10 .1^{40}$. A haplotype network to visualize the relationships among haplotypes representing seven Brazilian states was reconstructed using NETWORK 4.5.0.2 (Fluxus Technology Ltd.), with gaps and missing data excluded ${ }^{41}$.

\section{Declarations}

\section{ACKNOWLEDGMENTS}

The authors thank Rede de Pesquisa Ramularia for sampling of Ramulariopsis isolates in the main cotton producing regions in Brazil.

\section{FUNDING}

This study was financed in part by the Coordenação de Aperfeiçoamento de Pessoal de Nível Superior, Brazil (CAPES), Finance Code 001 and the Universidade de Brasília (UnB). We also acknowledge the financial support of the Conselho Nacional de Pesquisa (CNPq) and Fundação de Apoio a Pesquisa do Distrito Federal (FAP-DF) through grants 432974/2016-4 and 0193.001491/2017, respectively. D. B. Pinho and R.N.G. Miller acknowledge Conselho Nacional de Desenvolvimento Científico e Tecnológico (CNPq) for the research productivity fellowships.

\section{Author contributions}


All authors contributed to the study conception and design. Material preparation, data collection and analysis were performed by A.S.S., M.H.L.R., A.C.R.Q. and D.B.P. Conceptualization and review and editing were performed by A.C.C-F, A.E.A. and R.N. G.M. The first draft of the manuscript was written by A.S.S. and all authors commented on previous versions of the manuscript. All authors read and approved the final manuscript.

\section{Competing interests}

The authors declare no competing interests.

\section{Data availability}

The datasets generated in this study can be found in Genbank: MZ039858-MZ040124, and Xxxxxxxxxxxxxxxx; Treebase: S28159. The results obtained in this study are included in the contents of this report.

\section{Author information}

\section{Affiliations}

\section{Graduate Programme in Plant Pathology, Universidade de Brasília, Brasília, DF, 70910-900, Brazil}

Danilo Batista Pinho (orcid: 0000-0003-2624-302X), Aline Suelen da Silva (orcid: 0000-0002-0550-5847), Marcelo Henrique Lisboa Rennó (orcid: 0000-0001-5195-9930), Ana Clara Ribeiro Quitania (orcid: 00000002-8166-7127), Adalberto Corrêa Café-Filho (orcid: 0000-0002-5204-2961), Robert Neil Gerard Miller (orcid: 0000-0002-5798-4552).

\section{Embrapa Algodão, Campina Grande, PB, Brazil}

Alderi Emídio de Araújo (orcid: 0000-0003-0257-1539)

\section{Ethics declarations}

\section{Conflicts of interest}

The authors declare no conflict of interest.

\section{References}

1. Santos, R. F. \& Barros, M. A. L. Economia do Algodão in Algodão: o produtor pergunta, a Embrapa responde (eds. Beltrão, N. E. M. \& Araújo, A. E.) 21『32 (Embrapa Algodão, 2004).

2. Companhia Nacional de Abastecimento. Acompanhamento da safra brasileira de grãos. https://www.conab.gov.br/info-agro/safras/graos (2020).

3. Rodrigues, J. C. J. Algodão no Brasil: Mudança, Associativismo e Crescimento in Algodão no Cerrado do Brasil (ed. Freire, E. C.) 3 ed., $21 \otimes 38$ (Positiva, 2015). 
4. Silva, J. C., Bettiol, W. \& Suassuna, N. D. Ramularia leaf spot: an emergent disease of cotton in Brazil. Tropical Plant Pathology, 44, 473 \ https://doi.org/10.1007/s40858-019-00308-w (2019).

5. Xavier, T. W. et al. Identification of ramularia leaf blight cotton disease infection levels by multispectral, multiscale UAV imagery. Drones, 3(2), https://doi.org/10.3390/drones3020033 (2019).

6. Suassuna, N. D. \& Coutinho, W. M. Manejo das principais doenças do algodoeiro no Cerrado brasileiro in Algodão no Cerrado do Brasil (ed. Freire, E. C.) 3 ed., $365 \otimes 408$ (Positiva, 2015).

7. Spegazzini, C. Fungi guaranitici. Pugillus I. Anales de la Sociedad Científica Argentina, 22(4), 209 (1886).

8. Atkinson, G. F. A new Ramularia on cotton in Botanical gazette (eds. Arthur, J. C., Barnes, C. R. \& Coulter, J. M.) 15, $166 \otimes 168$ (Carlon \& Hollenbeck, 1890).

9. Chitarra, L. G. Identificação e Controle das Principais Doenças do Algodoeiro. 3 ed., 1 \82 (Embrapa Algodão, 2014).

10. Farr, D. F. \& Rossman, A. Y. Fungal Databases, U.S. National Fungus Collections, ARS, USDA. https://nt.ars-grin.gov/fungaldatabases/ (2021)

11. Ehrlic, E. \& Wolf, F. A. Areolate Mildew of Cotton. Phytopathology, 22, $229 \rrbracket 240$ (1932).

12. Tormen, N. R. \& Blum, L. E. B. Ramularia leaf spot effect on yield and fiber quality of cotton submitted to fungicide application. Revista Caatinga, 32, 634 \ https://doi.org/10.1590/198321252019v32n308rc(2019).

13. Suassuna, N. D., Chitarra, L. G., Asmus, G. L. \& Inomoto, M. M. Manejo de doenças do algodoeiro. Circular técnica 97. https://www.infoteca.cnptia.embrapa.br/bitstream/doc/274818/1/CIRTEC97.pdf (2006).

14. Braun, U. Studies on Ramularia and allied genera (VI). Nova Hedwigia, 56, 432 \ 433 (1993).

15. Videira, S. I. R., Groenewald, J. Z., Braun, U., Shin, H. D. \& Crous, P. W. All that glitters is not Ramularia. Studies in Mycology, 83, 49 \ https://doi.org/10.1016/j.simyco.2016.06.001 (2016).

16. Curvelo, C. R. S., Rodrigues, F. A., Berger, P. G. \& Rezende, D. C. Microscopia eletrônica de varredura do processo infeccioso de Ramularia areola em folhas de algodoeiro. Tropical Plant Pathology, 35 (2), $108 \otimes$ https://doi.org/10.1590/S1982-56762010000200006 (2010).

17. Mehta, Y.R. et al. Mycosphaerella areola - the teleomorph of Ramularia areola of cotton in Brazil, and its epidemiological significance. American Journal of Plant Sciences, 7, 1415 \ 1422. https://doi.org/4236/ajps.2016.710135 (2016).

18. Crous, P. W., Groenewald, J. Z., Risède, J., Simoneau, P. \& Hywel-Jones, N. L. Calonectria species and their Cylindrocladium anamorphs: species with sphaeropedunculate vesicles. Studies in Mycology, 50, $415 \otimes$ https://doi.org/10.3114/sim.55.1.213 (2004).

19. Decloquement, J. et al. Phytophthora theobromicola nov.: A new species causing black pod disease on Cacao in Brazil. Frontiers in Microbiology, 15, $1 \otimes 15$. https://doi.org/10.3389/fmicb.2021.537399 (2021). 
20. Videira, S. I. R. et al. Elucidating the Ramularia eucalypti species complex. Persoonia, 34, 50 \ https://doi.org/10.3767/003158515X685670 (2015).

21. Pezenti, L. F. et al. Phenotypic Variability among Isolates of Ramularia areola from Brazilian Cotton. Tropical Plant Pathology, 38 (4), 329 \& https://doi.org/10.1590/S1982-56762013005000023(2013).

22. Girotto, L. et al. Identification of Phenotypic and Genotypic Variability among the Isolates of Ramularia areola of Brazilian Cotton. American Journal of Plant Sciences, 4(9), 1893 \ 1898. https://doi.org/4236/ajps.2013.49232 (2013).

23. Zandona, C. et al. Mechanisms of resistance and presence of different resistance genes to Ramularia areola in two cotton genotypes. Tropical Plant Pathology, 37(3), $175 \rrbracket$ https://doi.org/10.1590/S1982-56762012000300002(2012).

24. Beltrão, N. E. M. Origem e evolução do algodoeiro in Algodão: o produtor pergunta, a Embrapa responde (eds. Beltrão, N. E. M. \& Araujo, A. E.) $15 \otimes 20$ (Embrapa Algodão, 2004).

25. Ganiger, M., Ashtaputre, S. A. \& Kulkarni, V. R. Molecular variability of Ramularia areola isolates causing grey mildew of cotton. Journal of Farm Sciences, 30 (2), 216 《 http://14.139.155.167/.../8652 (2017).

26. Lücking, R. et al. Unambiguous identification of fungi: where do we stand and how accurate and precise is fungal DNA barcoding?. IMA Fungus, 11 (14), 1 \ https://doi.org/10.1186/s43008-02000033-z (2020).

27. Santos, K. M. et al. Novel specific primers for rapid identification of Macrophomina European Journal of Plant Pathology, 156, 1213 《 1218. https://doi.org/10.1007/s10658-020-01952-8 (2020).

28. Ramanagouda, G., Ashtaputre, S. A. Collection and characterization of grey mildew (Ramularia areola) pathogen of cotton. Indian Phytopathology, 72, $301 \otimes 307$. https://doi.org/10.1007/s42360019-00123-y (2019).

29. Alfenas, A. C., Ferreira, F. A., Mafia, R. G. \& Gonçalves, R. C. Isolamento de fungos fitopatogênicos in Métodos em fitopatologia (eds. Alfenas, A. C. \& Mafia, R. G.) 2 ed., 55 \91 (UFV, 2016).

30. Castellani, A. Viability of some pathogenic fungi in distilled water. J. Trop. Med. Hyg. 24, $270 \otimes 276$ (1939).

31. Katoh, K. \& Standley, D. M. MAFFT Multiple sequence alignment software version 7: improvements in performance and usability. Molecular Biology and Evolution, 30, 772 $₫ 780$. https://doi.org/10.1093/molbev/mst010 (2013).

32. Miller, M. A., Pfeiffer, W. \& Schwartz, T. "Creating the CIPRES Science Gateway for inference of large phylogenetic trees," in Proceedings of the Gateway Computing Environments Workshop (GCE), New Orleans, LA, $1 \otimes 8$. https://doi.org/1109/GCE.2010.5676129 (2010).

33. Ronquist, F. \& Huelsenbeck, J. P. MrBayes 3: Bayesian phylogenetic inference under mixed models. Bioinformatics, 19 (12), $1572 \otimes$ https://doi.org/10.1093/bioinformatics/btg180 (2003).

34. Rambaut, A., Drummond, A. Tracer MCMC trace analysis tool. http://tree.bio.ed.ac.uk/software/tracer/ (2018). 
35. Stamatakis, A. RAxML version 8: a tool for phylogenetic analysis and post-analysis of large phylogenies. Bioinformatics, 30, 1312 \ https://doi.org/10.1093/bioinformatics/btu033 (2014).

36. Rambaut, A. FigTree 4.0.http://tree.bio.ed.ac.uk/software/figtree/ (2012)

37. Gente, S., Sohier, D., Coton, E., Duhamel, C. \& Guéguen, M. Identification of Geotrichum candidum at the species and strain level: proposal for a standardized protocol. Ind. Microbiol. Biotechnol., 33, $1019 \otimes 1031$. https://doi.org/10.1007/s10295-006-0130-3 (2006).

38. Santana, M. F., Batista, A. D., Ribeiro, L. E., Araújo, E. F. \& Queiroz, M. V. Terminal repeat retrotransposons as DNA markers in fungi. Journal of Basic Microbiology, 53 (10), 823 《 https://doi.org/10.1002/jobm.201200453 (2012).

39. Hammer, O., Harper, D. A. T. \& Ryan, P. D. Paleontological statistics software: package for education and data analysis. Palaeontologia Electronica, 4 (1), 1 ه 9 (2001).

40. P. J. R. \& Rozas, J. DnaSP v5: A software for comprehensive analysis of DNA polymorphism data. Bioinformatics,25(11), 1451 \1452. https://doi.org/10.1093/bioinformatics/btp187 (2009).

41. Bandelt, H. J., Forster, P. \& Roehl, A. Median-joining networks for inferring intraspecific phylogenies. Mol. Biol. Evol., 16, $37 \otimes 48$. https://doi.org/1093/oxfordjournals.molbev.a026036 (1999).

42. Jacobs, K., Bergdahl, D. R., Wingfield, M. J., Halik, S., Seifert, K. A., Bright, D. E. \& Wingfield, B. D. Leptographium wingfieldii introduced into North America and found associated with exotic Tomicus piniperda and native bark beetles. Res., 108 (4), $411 \otimes 418$.

https://doi.org/10.1017/S0953756204009748 (2004).

43. Hoog, G. S. \& Ende, A. H. G. Molecular diagnostics of clinical strains of filamentous Basidiomycetes. Mycoses, 41(5-6), $183 \otimes$ https://doi.org/10.1111/j.1439-0507.1998.tb00321.x (1998).

44. Vilgalys, R. \& Hester, M. Rapid genetic identification and mapping of enzymatically amplified ribosomal DNA from several Cryptococcus Journal of Bacteriology, 172(8), 4238 ه 4246. https://doi.org/10.1128/jb.172.8.4238-4246.1990 (1990).

45. Carbone, I. \& Kohn, L. M. A method for designing primer sets for speciation studies in filamentous ascomycetes. Mycologia, 91(3), $553 \otimes$ https://doi.org/10.1080/00275514.1999.12061051 (1999).

46. Liu, Y. J., Whelen, S. \& Hall, B. D. Phylogenetic Relationships Among Ascomycetes: Evidence from an RNA Polymerse II Subunit. Biol. Evol., 16(12), 1799 \& 1808. https://doi.org/10.1093/oxfordjournals.molbev.a026092 (1999).

47. Stern, M. J., Ames, G. F. L., Smith, N. H., Robinson, E. C. \& Higgins, C. F. Repetitive extragenic palindromic sequences: a major component of the bacterial genome. Cell, 37 (3), 1015 \ https://doi.org/10.1016/0092-8674(84)90436-7 (1984).

48. Hulton, C. S., Higgins, C. F. \& Sharp, P. M. ERIC sequences: a novel family of repetitive elements in the genomes of Escherichia coli, Salmonela typhimuriumand other enterobacteria. Molecular Microbiology, 5 (4), 825 \https://doi.org/10.1111/j.1365-2958.1991.tb00755.x (1991).

49. Martin, B. et al. A highly conserved repeated DNA element located in the chromosome of Steptococcus pneumoniae. Nucleic Acid Research, 20 (13), 3479 \ https://doi.org/10.1093/nar/20.13.3479 (1992). 
50. Bulat, S. A. \& Mironenko, N. V. \& Zholkevich, Y. G. Genetic structure of soil population of fungus Fusarium oxysporum: Fr.: Molecular reidentification of the species and genetic differentiation of isolates using polymerase chain reaction technique with universal primers (UP PCR). Russian Journal of Genetics, 31 (3), $271 \otimes 278$ (1995).

51. Vassart, G. et al. A sequence in M13 phage detects hypervariable minisatellites in human and animal DNA. Science, 235(4789), $683 \otimes$ https://doi.org/10.1126/science.2880398 (1987).

52. Santos, L. V. et al. Development of new molecular markers for the Colletotrichum genus using RetroCl1 sequences. World Journal of Microbiology and Biotechnology, 28(3), 1087 区https://doi.org/10.1007/s11274-011-0909-x (2011).

53. Rodrigues, R. J. \& Yoder, O. C. A family of conserved repetitive DNA elements from the fungal plant pathogen Glomerella cingulata (Colletotrichum lindemathianum). Experiment Micology, 15, 232 《 https://doi.org/10.1016/0147-5975(91)90025-9 (1991).

54. Andrea, G. \& Xitlali, Inter Simple Sequence Repeats (ISSRs) in Ecología Molecular (eds. Eguiarte, L. E., Souza, V. \& Xitlali, A.) 567 ه 571 (INE, 2007).

55. Weising, K. et al. Polymorphic simple GATA/GACA repeats in plant genomes. Nucleic Acids Research, 17 (23), https://doi.org/10.1093/nar/17.23.10128 (1989).

\section{Tables}

Table 1. Primers selected for phylogenetic analysis and inter and intraspecific diversity analysis of Ramulariopsis isolates. 


\begin{tabular}{|c|c|c|c|c|c|}
\hline Locus $^{1,2}$ & $\begin{array}{l}\text { Primer } \\
\text { Name }\end{array}$ & Sequence $5^{\prime} \rightarrow 3^{\prime}$ & Orientation & References & $\begin{array}{l}\text { (Anelling/ } \\
\text { Extension) }\end{array}$ \\
\hline \multirow[t]{2}{*}{ Elongation factor $1-\alpha(E F 1 \alpha)^{1}$} & EF1F & $\begin{array}{l}\text { TGC GGT GGT ATC } \\
\text { GAC AAG CGT }\end{array}$ & Forward & $\begin{array}{l}\text { Jacobs et } \\
\text { al. }{ }^{42}\end{array}$ & $54^{\circ}-45^{\prime \prime} / 72^{\circ}-45^{\prime \prime}$ \\
\hline & EF2R & $\begin{array}{l}\text { AGC ATG TTG TCG } \\
\text { CCG TTG AAG }\end{array}$ & Reverse & $\begin{array}{l}\text { Jacobs et } \\
\text { al. }^{42}\end{array}$ & $54^{\circ}-45^{\prime \prime} / 72^{\circ}-45^{\prime \prime}$ \\
\hline \multirow[t]{2}{*}{ Histone H3 (HIS3) ${ }^{1}$} & CYLH3F & $\begin{array}{l}\text { AGG TCC ACT GGT } \\
\text { GGC AAG }\end{array}$ & Forward & $\begin{array}{l}\text { Crous et } \\
\text { al. }{ }^{18}\end{array}$ & $60^{\circ}-45^{\prime \prime} / 72^{\circ}-30^{\prime \prime}$ \\
\hline & CYLH3R & $\begin{array}{l}\text { AGC TGG ATG TCC } \\
\text { TTG GAC TG }\end{array}$ & Reverse & $\begin{array}{l}\text { Crous et } \\
\text { al. }{ }^{18}\end{array}$ & $60^{\circ}-45^{\prime \prime} / 72^{\circ}-30^{\prime \prime}$ \\
\hline \multirow[t]{2}{*}{$\begin{array}{l}\text { 28S nrRNA (LSU) e Internal } \\
\text { transcribed spacer (ITS) }{ }^{1}\end{array}$} & V9G & $\begin{array}{l}\text { TTA CGT CCC TGC } \\
\text { CCT TTG TA }\end{array}$ & Forward & $\begin{array}{l}\text { De Hoog \& } \\
\text { Ende }^{43}\end{array}$ & $53^{\circ}-45^{\prime \prime} / 72^{\circ}-45^{\prime \prime}$ \\
\hline & LR5 & $\begin{array}{l}\text { ATC CTG AGG GAA } \\
\text { ACT TC }\end{array}$ & Reverse & $\begin{array}{l}\text { Vilgalys \& } \\
\text { Hester } 44\end{array}$ & $53^{\circ}-45^{\prime \prime} / 72^{\circ}-45^{\prime \prime}$ \\
\hline \multirow[t]{2}{*}{$\operatorname{Actin}(\mathrm{ACT})^{1}$} & ACT-512F & $\begin{array}{l}\text { ATG TGC AAG GCC } \\
\text { GGT TTC GC }\end{array}$ & Forward & $\begin{array}{l}\text { Carbone \& } \\
\text { Kohn }^{45}\end{array}$ & $58^{\circ}-25^{\prime \prime} / 72^{\circ}-25^{\prime \prime}$ \\
\hline & $\begin{array}{l}\text { ACT- } \\
783 R\end{array}$ & $\begin{array}{l}\text { TAC GAG TCC TTC } \\
\text { TGG CCC AT }\end{array}$ & Reverse & $\begin{array}{l}\text { Carbone \& } \\
\text { Kohn }^{45}\end{array}$ & $58^{\circ}-25^{\prime \prime} / 72^{\circ}-25^{\prime \prime}$ \\
\hline \multirow[t]{2}{*}{$\begin{array}{l}\text { RNA polymerase II second } \\
\text { largest subunit (RPB2) }{ }^{1}\end{array}$} & RPB2-5f & $\begin{array}{l}\text { GAY GAY MGW GAT } \\
\text { CAY TTY GG }\end{array}$ & Forward & Liu et al. ${ }^{46}$ & $54^{\circ}-45^{\prime \prime} / 72^{\circ}-45^{\prime \prime}$ \\
\hline & $7 \mathrm{cR}$ & $\begin{array}{l}\text { CCC ATR GCT TGY } \\
\text { TTR CCC AT }\end{array}$ & Reverse & Liu et al. ${ }^{46}$ & $54^{\circ}-45^{\prime \prime} / 72^{\circ}-45^{\prime \prime}$ \\
\hline \multirow[t]{2}{*}{$\mathrm{REP}^{2}$} & REP1R-1 & $\begin{array}{l}\text { III ICG ICG ICA TCI } \\
\text { GGC }\end{array}$ & Forward & $\begin{array}{l}\text { Stern et } \\
\text { al. }^{47}\end{array}$ & $44^{\circ}-60^{\prime \prime} / 72^{\circ}-8^{\prime}$ \\
\hline & REP2-1 & $\begin{array}{l}\text { ICG ICT TAT CIG } \\
\text { GCC TAC }\end{array}$ & Reverse & $\begin{array}{l}\text { Stern et } \\
\text { al. }^{47}\end{array}$ & $44^{\circ}-60^{\prime \prime} / 72^{\circ}-8^{\prime}$ \\
\hline \multirow[t]{2}{*}{ ERIC $^{2}$} & ERIC1R & $\begin{array}{l}\text { ATG TAA GCT CCT } \\
\text { GGG GAT TCA C }\end{array}$ & Forward & $\begin{array}{l}\text { Hulton et } \\
\text { al. }{ }^{48}\end{array}$ & $52^{\circ}-60^{\prime \prime} / 72^{\circ}-8^{\prime}$ \\
\hline & ERIC2 & $\begin{array}{l}\text { AAG TAA GTG ACT } \\
\text { GGG GTG AGC G }\end{array}$ & Reverse & $\begin{array}{l}\text { Hulton et } \\
\text { al. }{ }^{48}\end{array}$ & $52^{\circ}-60^{\prime \prime} / 72^{\circ}-8^{\prime}$ \\
\hline $\mathrm{BOX}^{2}$ & BOXA1R & $\begin{array}{l}\text { CTA CGG CAA GGC } \\
\text { GAC GCT GAC G }\end{array}$ & - & $\begin{array}{l}\text { Martin et } \\
\text { al. }{ }^{49}\end{array}$ & $53^{\circ}-60^{\prime \prime} / 72^{\circ}-8^{\prime}$ \\
\hline Universal primer N21 ${ }^{2}$ & N21 & $\begin{array}{l}\text { GGA TCC GAG GGT } \\
\text { GGC GGT TCT }\end{array}$ & - & $\begin{array}{l}\text { Bulat et } \\
\text { al. }{ }^{50}\end{array}$ & $55^{\circ}-45^{\prime \prime} / 72^{\circ}-90^{\prime \prime}$ \\
\hline Universal primer M13 ${ }^{2}$ & M13 & $\begin{array}{l}\text { GAG GGT GGC GGT } \\
\text { TCT }\end{array}$ & - & $\begin{array}{l}\text { Vassart et } \\
\text { al. }^{51}\end{array}$ & $50^{\circ}-45^{\prime \prime} / 72^{\circ}-90^{\prime \prime}$ \\
\hline \multirow[t]{3}{*}{ IRAP $^{2}$} & CIIRAP1 & $\begin{array}{l}\text { CGT ACG GAA CAC } \\
\text { GCT ACA GA }\end{array}$ & - & $\begin{array}{l}\text { Santos et } \\
\text { al. }^{52}\end{array}$ & $57,5^{\circ}-30^{\prime \prime} / 72^{\circ}-120^{\prime \prime}$ \\
\hline & CIIRAP2 & $\begin{array}{l}\text { AAT AAC GTC TCG } \\
\text { GCC TTC AG }\end{array}$ & - & $\begin{array}{l}\text { Santana et } \\
\text { al. }{ }^{38}\end{array}$ & $\begin{array}{l}55,4^{\circ}-30^{\prime \prime} \mid \\
72^{\circ}-120^{\prime \prime}\end{array}$ \\
\hline & CIIRAP4 & $\begin{array}{l}\text { CTT TTG ACG AGG } \\
\text { CCA TGC }\end{array}$ & - & $\begin{array}{l}\text { Santos et } \\
\text { al. }^{52}\end{array}$ & $\begin{array}{l}54,9^{\circ}-30^{\prime \prime} \mid \\
72^{\circ}-120^{\prime \prime}\end{array}$ \\
\hline \multirow[t]{5}{*}{ ISSR $^{2}$} & $(\mathrm{CAG})^{5}$ & $\begin{array}{l}\text { CAG CAG CAG CAG } \\
\text { CAG }\end{array}$ & - & $\begin{array}{l}\text { Rodrigues } \\
\text { et al. }{ }^{53}\end{array}$ & $60^{\circ}-45^{\prime \prime} / 72^{\circ}-90^{\prime \prime}$ \\
\hline & $(\mathrm{GA})^{8}$ & $\begin{array}{l}\text { GAG AGA GAG AGA } \\
\text { GAG A }\end{array}$ & - & $\begin{array}{l}\text { Andrea \& } \\
\text { Xitlali }^{54}\end{array}$ & $44^{\circ}-45^{\prime \prime} / 72^{\circ}-90^{\prime \prime}$ \\
\hline & $(\mathrm{GACAC})^{3}$ & $\begin{array}{l}\text { GAC ACG ACA CGA } \\
\text { CAC }\end{array}$ & - & $\begin{array}{l}\text { Weising et } \\
\text { al. }^{55}\end{array}$ & $48^{\circ}-45^{\prime \prime} / 72^{\circ}-90^{\prime \prime}$ \\
\hline & $(\mathrm{TGTC})^{4}$ & $\begin{array}{l}\text { TGT CTG TCT GTC } \\
\text { TGT C }\end{array}$ & - & $\begin{array}{l}\text { Rodrigues } \\
\text { et al. }{ }^{53}\end{array}$ & $48^{\circ}-45^{\prime \prime} / 72^{\circ}-90^{\prime \prime}$ \\
\hline & $(\mathrm{GTG})^{5}$ & $\begin{array}{l}\text { GTG GTG GTG GTG } \\
\text { GTG }\end{array}$ & - & $\begin{array}{l}\text { Gente et } \\
\text { al. }^{37}\end{array}$ & $58^{\circ}-45^{\prime \prime} / 72^{\circ}-90^{\prime \prime}$ \\
\hline
\end{tabular}




\begin{tabular}{|c|c|c|c|c|c|}
\hline Locus $^{1,2}$ & $\begin{array}{l}\text { Primer } \\
\text { Name }\end{array}$ & Sequence $5^{\prime} \rightarrow 3^{\prime}$ & Orientation & References & $\begin{array}{l}\text { (Anelling/ } \\
\text { Extension) }\end{array}$ \\
\hline & $(\text { GACA })^{4}$ & $\begin{array}{l}\text { GAC AGA CAG ACA } \\
\text { GAC A }\end{array}$ & - & $\begin{array}{l}\text { Gente et } \\
\text { al. }\end{array}$ & $50^{\circ}-45^{\prime \prime} / 72^{\circ}-90^{\prime \prime}$ \\
\hline & $(\mathrm{GATA})^{4}$ & $\begin{array}{l}\text { GAT AGA TAG ATA } \\
\text { GAT A }\end{array}$ & - & $\begin{array}{l}\text { Gente et } \\
\text { al. }^{37}\end{array}$ & $35^{\circ}-45^{\prime \prime} / 72^{\circ}-90^{\prime \prime}$ \\
\hline
\end{tabular}

1 Molecular marker used for multigenic analysis.

2 Molecular marker used to analyze inter and intraspecific diversity.

Table 2. Morphometric characteristics of Ramulariopsis gossypii and $R$. pseudoglycines on Gossypium hirsutum (Malvaceae).

\begin{tabular}{|c|c|c|c|}
\hline SPECIES & Conidiophore $\mu \mathrm{m}$ & Conidia $\mu \mathrm{m}$ & Host \\
\hline R. gossypii ${ }^{1}$ & $35-40 \times 3$ & $18-25 \times 3-4$ & G. hirsutum \\
\hline R. pseudoglycines ${ }^{2}$ & $121-175 \times 2$ & $6.5-8 \times 2.5-3$ & G. hirsutum \\
\hline $\begin{array}{l}\text { R. gossypii CCUB 2939, } \\
\text { CCUB } 2883\end{array}$ & $25-44 \times 2.5-3.5$ & $13-19 \times 3.5-4.5$ & G. hirsutum \\
\hline $\begin{array}{l}\text { R. pseudoglycines } \\
\text { CCUB 2269, CCUB } 3304\end{array}$ & $74,5-138.5 \times 2.5-3$ & $11-21.5 \times 3-3.5$ & G. hirsutum \\
\hline
\end{tabular}

${ }^{1}$ (Spegazzini, 1886); ${ }^{2}$ (Videira et al., 2016).

Figures 


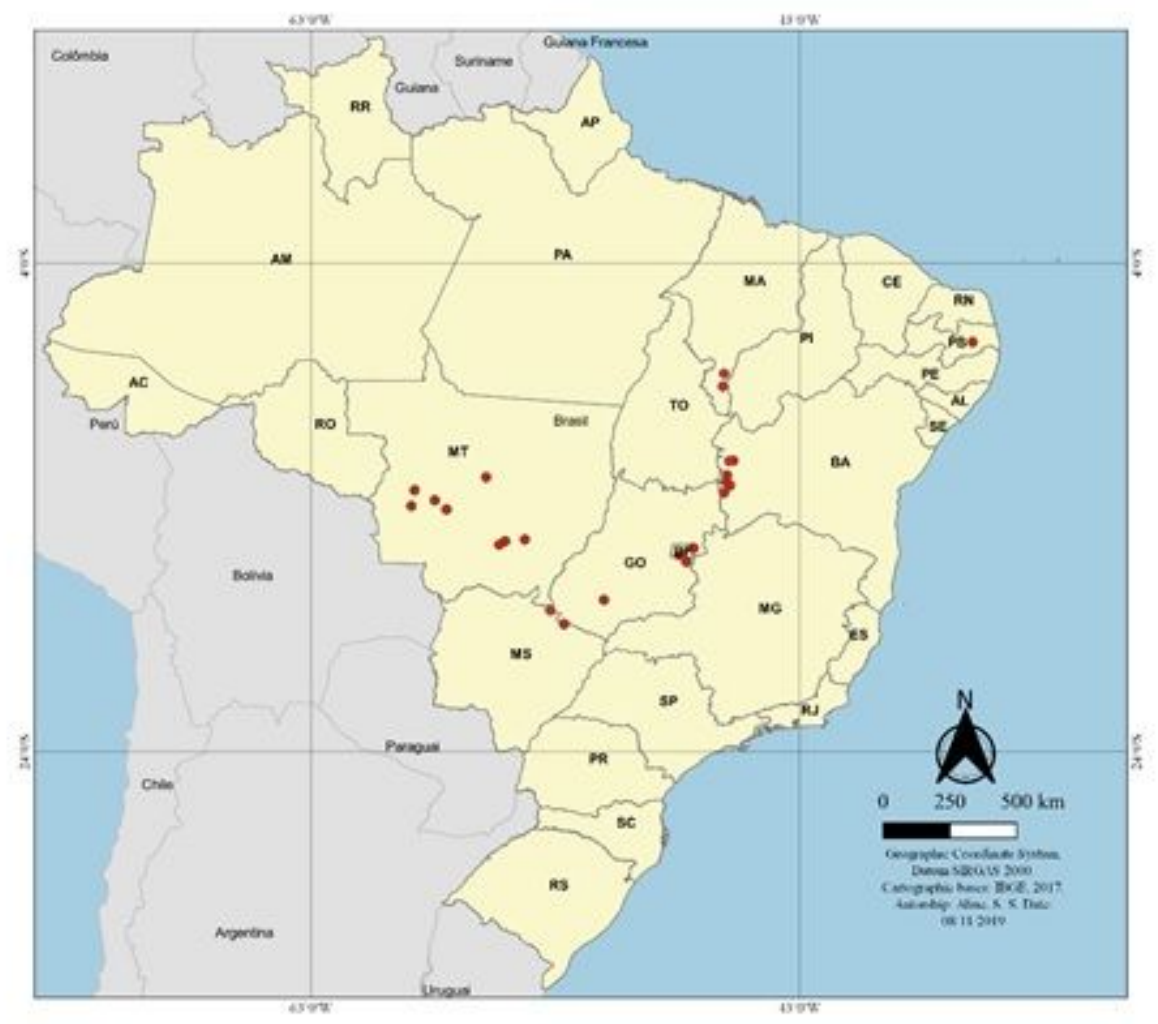

Figure 1

Map of Brazil showing the distribution of states and different collection points of Ramulariopsis isolates.
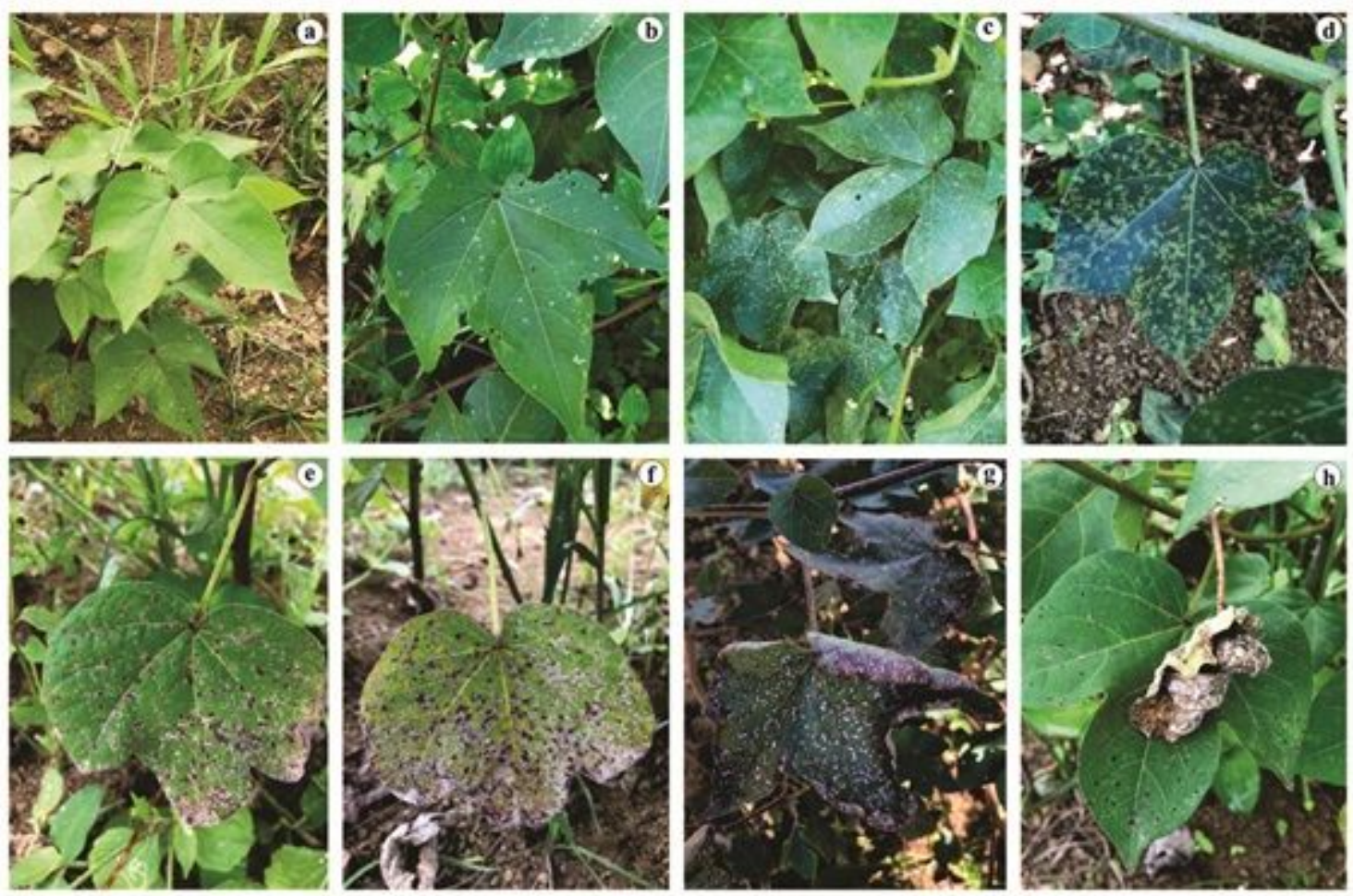

Figure 2 
(A-H) Ramularia leaf spot symptoms in cotton. A. Healthy leaves observed in the field. B, C, D. Initial symptoms; Early sporulation of Ramulariopsis on adaxial sides of cotton leaf; E, F. Late sporulation on necrotic lesions on the upper surface of cotton leaf; G. Necrotic lesions covering the leaf. H. Fallen leaf with advanced necrotic lesions.

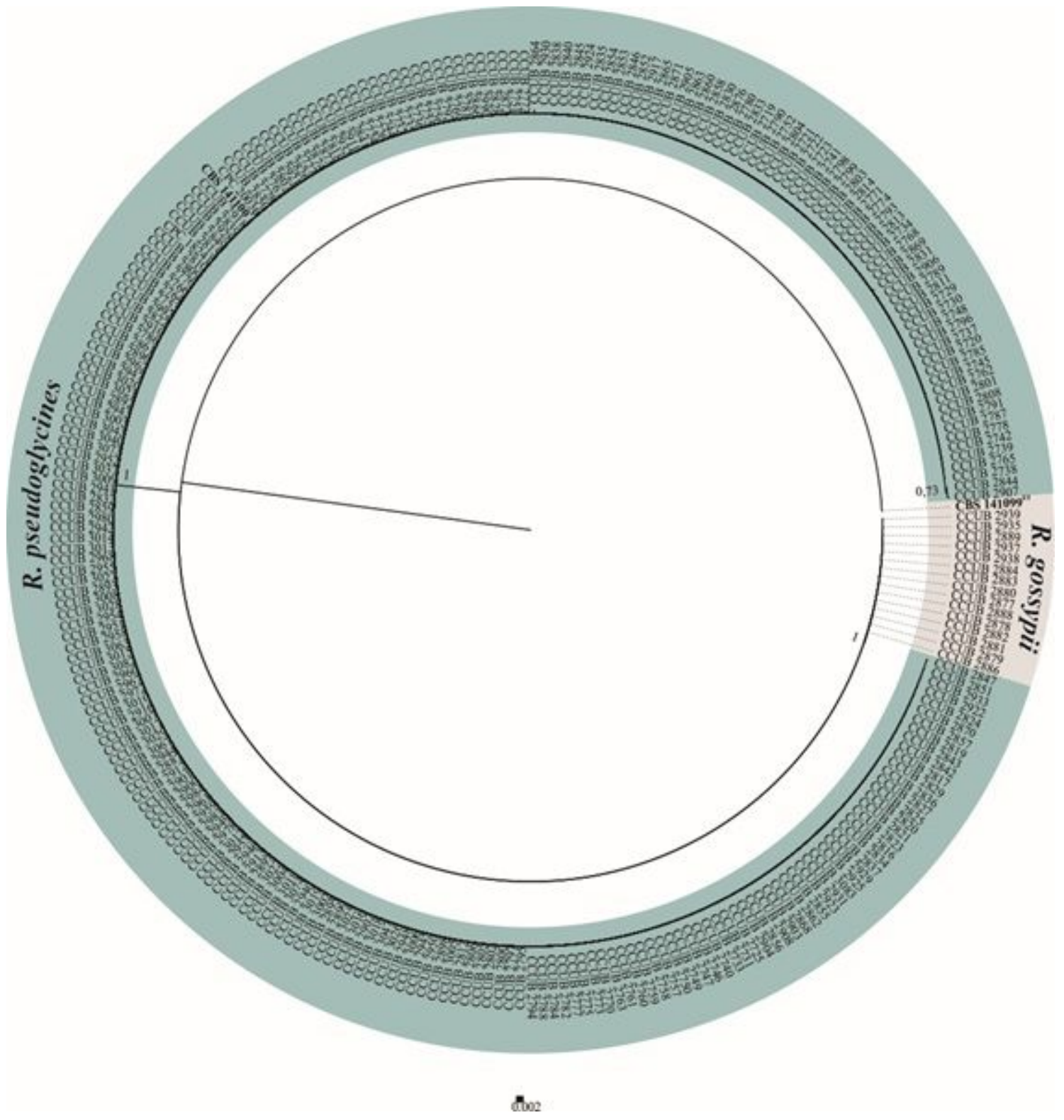

Figure 3

Bayesian phylogenetic tree based on RPB2 sequences of Ramulariopsis species. Bayesian posterior probabilities and Maximum Likelihood bootstrap support values are indicated at the nodes, and the scale bar represents the number of expected changes per site. Ex-type isolates are highlighted in bold. The extype CBS 141099 of Ramulariopsis gossypii was used as outgroup. 


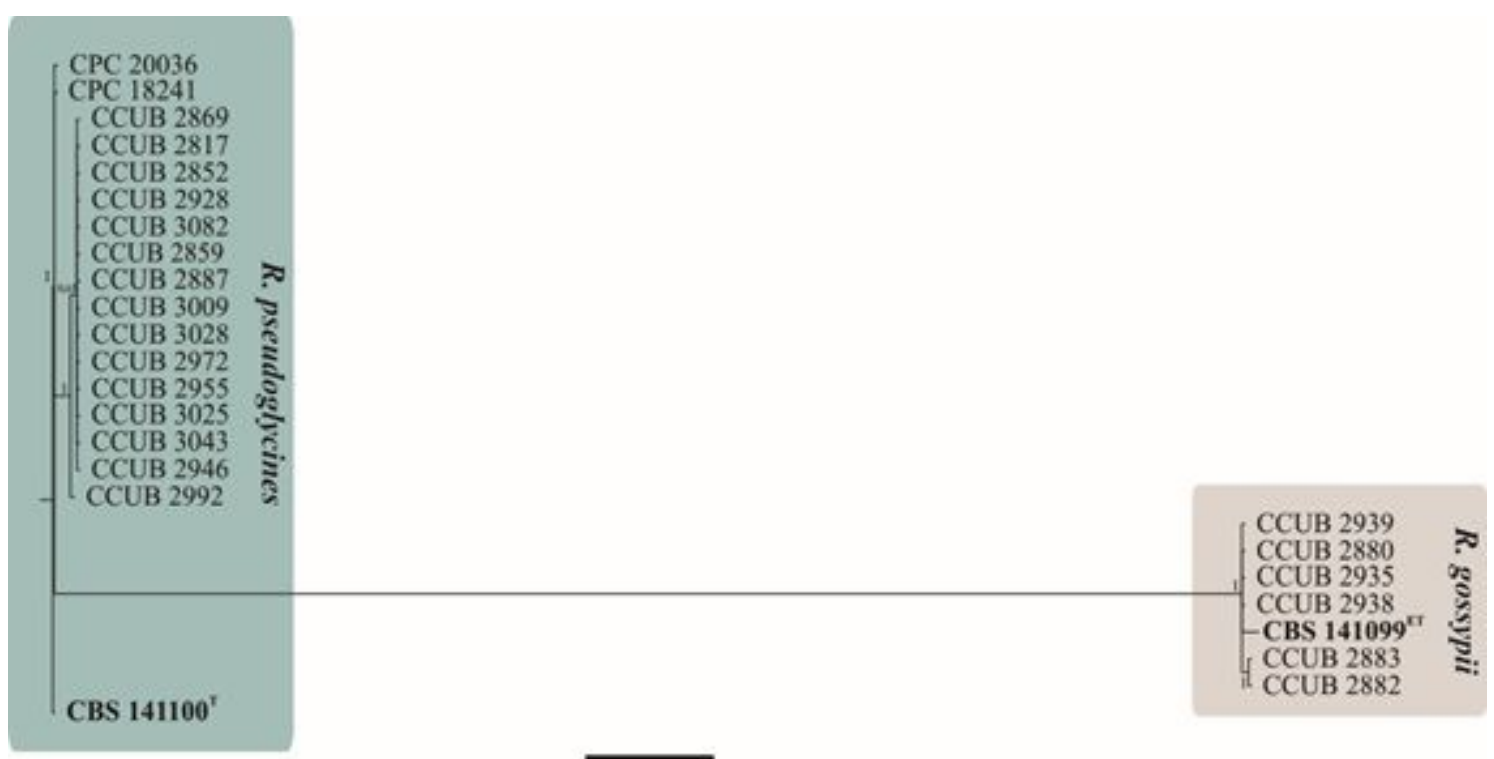

\section{Figure 4}

Bayesian phylogenetic tree based on concatenate sequences (RPB2, LSU, EF1- $a$, ITS, ACT, and HIS3) of Ramulariopsis species. Bayesian posterior probabilities and Maximum Likelihood bootstrap support values are indicated at the nodes, and the scale bar represents the number of expected changes per site. Ex-type isolates are highlighted in bold. The type CBS 141100 of Ramulariopsis pseudoglycines was used as outgroup. 

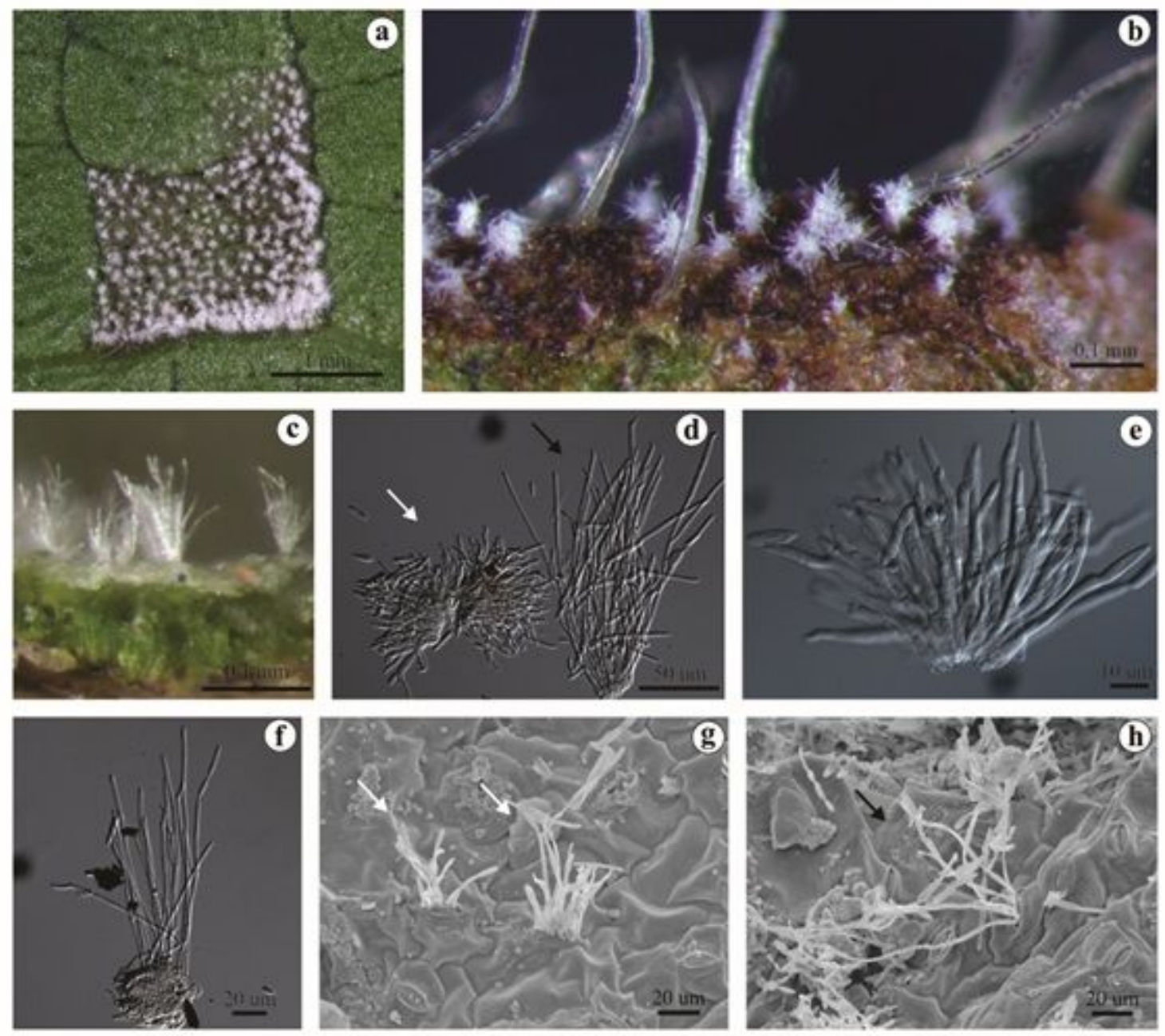

Figure 5

$(\mathrm{A}-\mathrm{H})$. Ramulariopsis spp. on leaves of Gossypium hirsutum. A. Lesion with signs of the fungus on the leaf abaxial face. B. Hyaline conidiophores of R. gossypii on the abaxial side of the leaves. C. Hyaline conidiophores of R. pseudoglycines on the abaxial side of the leaves. D. Hyaline conidiophores of R. gossypii (left) and R. pseudoglycines (right) viewed under light microscopy. E. Fascicle of R. gossypii formed by conidiophores with presence of hyaline conidia. F. Conidiophores of R. pseudoglycines. G. Conidiophores of R. gossypii visualized in SEM. H. Conidiophores of R. pseudoglycines visualized in SEM. 


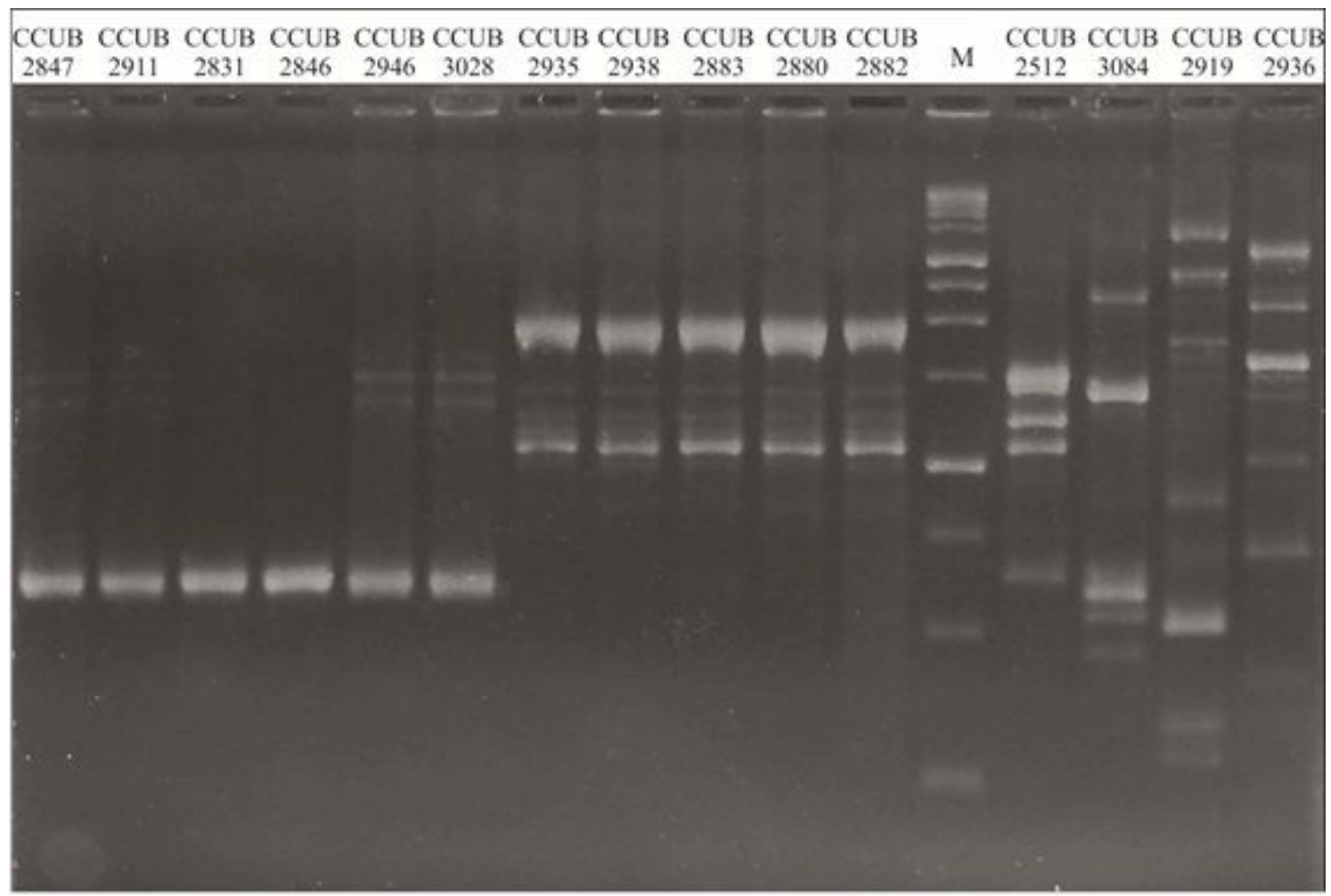

\section{Figure 6}

Amplicons visualized on 1.5\% agarose gel from the amplification of isolates of R. pseudoglycines (CCUB 2847, CCUB 2911, CCUB 2831, CCUB 2846, CCUB 2946, CCUB 3028), R. gossypii (CCUB 2935, CCUB 2938, CCUB 2883, CCUB 2880 and CCUB 2882), Fusarium sp. (CCUB 2512), Colletotrichum sp. (CCUB 3084), Talaromyces sp. (CCUB 2919) and Baudoinia sp. (CCUB 2936), using the ISSR (TGTC) 4 primer. $M=$ molecular marker $1 \mathrm{~Kb}$ DNA Ladder Thermo Scientific. 


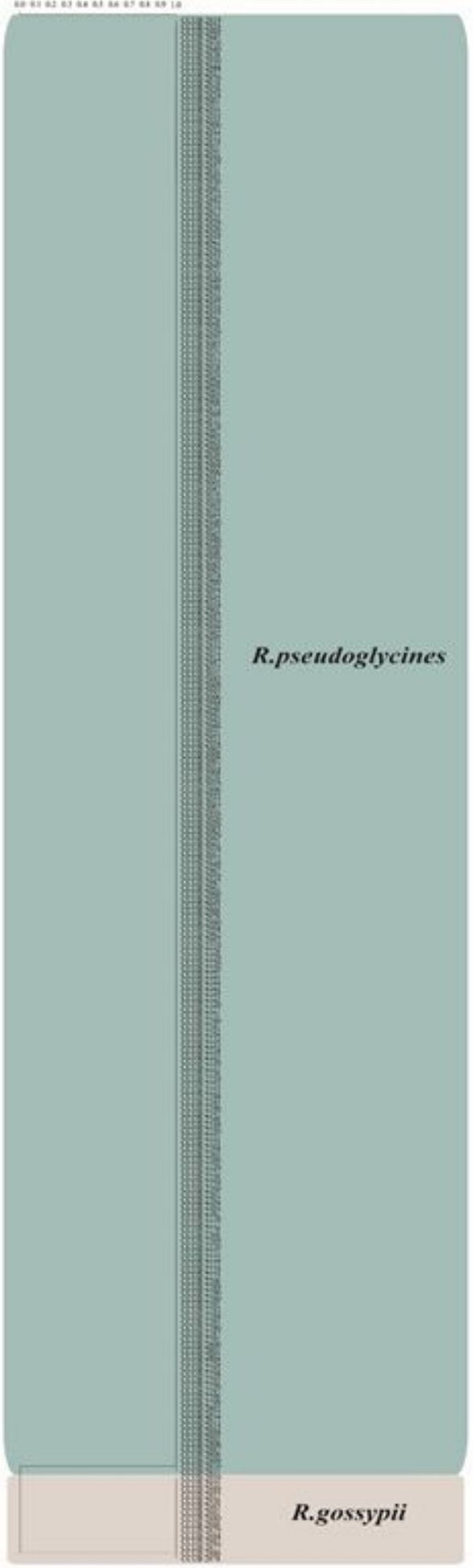

\section{Figure 7}

Dendrogram of 267 isolates of Ramulariopsis, generated by amplification with the ISSR (TGTC) 4 primer, with the cutoff close to $70 \%$ of similarity. Genetic similarity pattern generated by the UPGMA method, based on Jaccard's coefficient. 


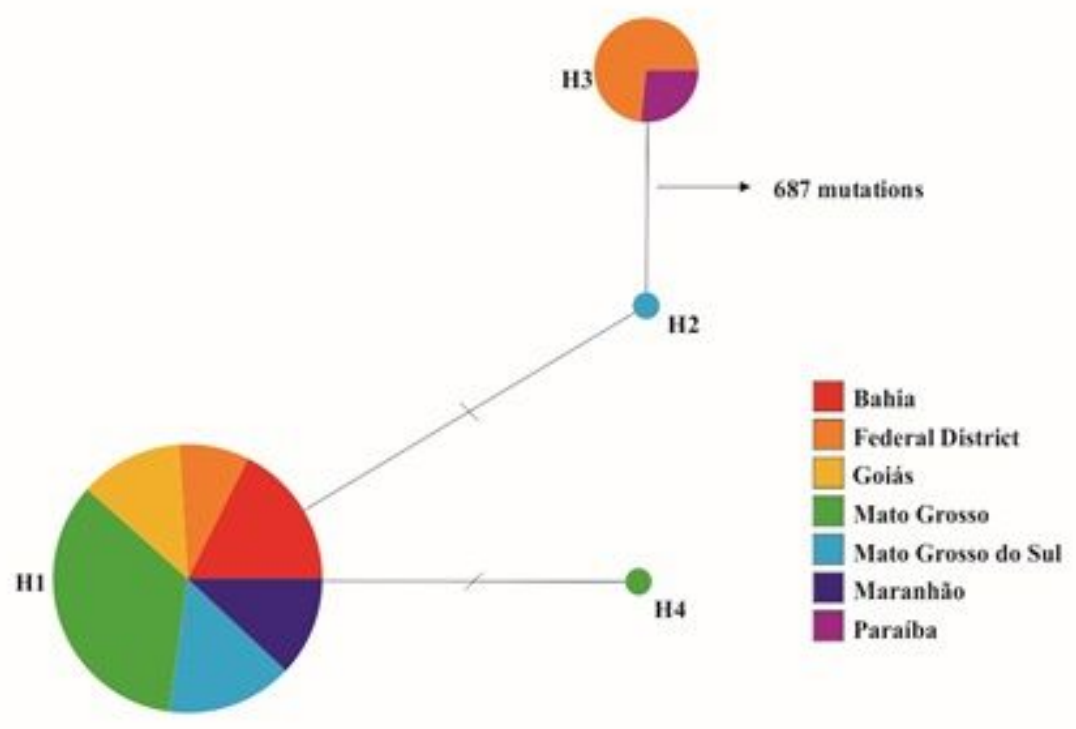

\section{Figure 8}

Haplotype network generated for RPB2 sequences representing seven Brazilian states using Network. Each circle represents a distinct haplotype, proportional in size to its' frequency in the sample. Hatch marks along the network branches indicate hypothetical mutational steps not detected in the dataset. Geographic origin of isolates from each haplotype is proportionally represented in pie charts by different colours.

\section{Supplementary Files}

This is a list of supplementary files associated with this preprint. Click to download.

- Silvaetal.SupplementaryScientificReports.docx 